\title{
A Critical Assessment of China's Role in the South China Sea Dispute
}

\author{
Junyuan Peng ${ }^{1} \&$ Jing Shi ${ }^{1}$ \\ ${ }^{1}$ Guangdong University of Foreign Studies, Guangdong, Guangzhou, Guangdong, China \\ Correspondence: Jing Shi, Guangdong University of Foreign Studies, Guangdong, Guangzhou, Guangdong, China. \\ E-mail: sj@oamail.gdufs.edu.cn
}

Received: September 5, 2020

Accepted: October 8, $2020 \quad$ Online Published: October 13, 2020

doi:10.5539/jpl.v13n4p169

URL: https://doi.org/10.5539/jpl.v13n4p169

\begin{abstract}
South China Sea is only a small part on the map, but it plays a vital role in the stability of the Pacific-Asian region. South China Sea issue has been under spotlight. Five countries have claimed their rights on these tiny islands splashed in the region of South China Sea. Spratly Islands (Nansha) is endowed with abundant natural resources of petroleum, gas, and others. China, as an emerging super power, plays an important role in maintaining the stability of the region. Which role will China play, a bull in the china shop or a coordinator in finding a peaceful solution? This paper attempts to answer this question by presenting a critical assessment of China's role in the South China Sea dispute.
\end{abstract}

Keywords: South China Sea, dispute, internal reason, external

\section{Introduction}

\subsection{An Introduction of the South China Sea and Its Claimant States}

'The semi-enclosed South China Sea occupies a 648,000 square-mile portion of the Pacific Ocean stretching from the Strait of Malacca in the southwest to the Strait of Taiwan in the northeast' (Burgess, 2003). This area consists of hundreds of small islands, atolls and reefs, most of which locate in the Paracel (Xisha) and Spratly (Nansha) group islands (Burgess, 2003). The most controversial one is the Spratly Islands. It is surprising that these small islands, among which only seven are more than 0.1 square kilometers in area and the largest one is only 625 yards wide, become the focus of a major international confrontation (Gallagher, 1994). The importance of these small islands comes from the strategic locations and the abundance of the energy and fishery resources of them. 


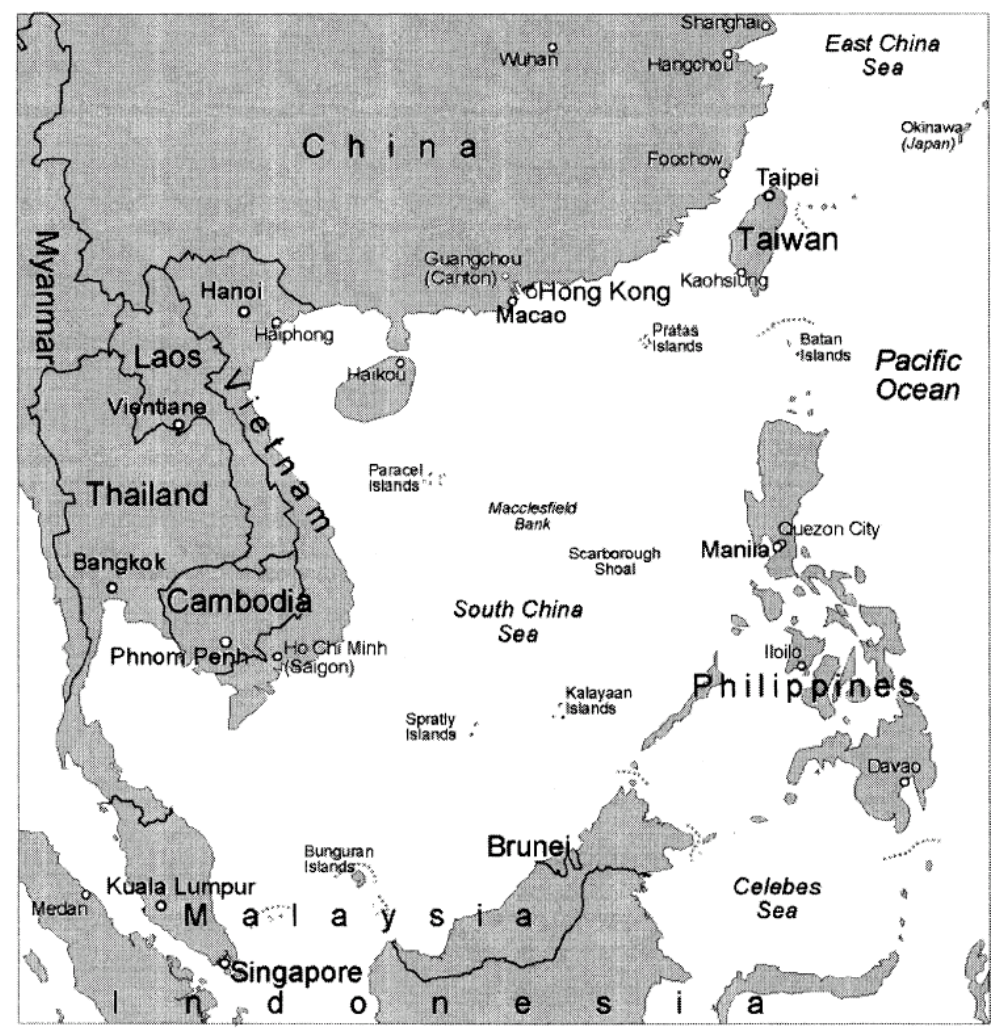

Figure 1. The South China Sea (Lee, 1999)

Five nation countries and Taiwan have overlapping claimants over the South China Sea. China claims almost the whole South China Sea based on historical and archaeological reasons (Burgess, 2003; Valencia, 1993). In 1947, China released a new map including almost the whole South China Sea within its territory and in 1992, it passed a law reasserting its sovereignty over it (Burgess, 2003). China at present occupies eight of the Paracel Islands and several reefs in the Spratlys in order to 'enforce' its claim (Burgess, 2003). Taiwan's claim over almost the entire South China Sea is also based on the same reasons as China and it occupies the largest island in the Spratlys to bolster its claim (Burgess, 2003; Valencia, 1993). In order to bolster its claim justified by historical and archaeological reasons over Spratlys, Paracels and an extensive portion of the South China Sea, Vietnam occupies most islands in the Spratlys among all the claimant states (Burgess, 2003). The Philippines claims submerged features in the Spratlys justified in their importance to the country's security and economic survival (Valencia, 1993). Malaysia claims several features in the southern Spratlys grounded on occupation (Burgess, 2003). Brunei claims no islands but a 200 nautical mile Exclusive Economic Zone (EEZ) running through the Spratlys (Valencia, 1993).

\subsection{The Latest Information of the South China Sea dispute}

South China Sea has become important route for trade and commerce, hence safety of transportation has become very important. In 2012, tensions flared between China and the Philippines over plans to drill for oil in the Reed Bank, a disputed shoal in the South China Sea, rekindling fears about the possibility of military conflict over the area's energy resources (Muscolino, 2013). As global energy demand has risen, claimants have devised plans to exploit the sea's hydrocarbon reserves with dispute, particularly between China and Vietnam, which has gone beyond territorial claims and access to energy resources, as the South China Sea has become a focal point for U.S.China rivalry in the Western Pacific (Buszynski, 2012). With increasing sea borne trade, shipping industries have gained momentum out of which 90 per cent of the ship building activities have occurred in China, Japan and the Republic of Korea. 5 Such a boost in the global maritime trade makes the SLOCs of the South China Sea critical. UNCTAD estimates that approximately 60 percent of this global maritime trade traverses through Asia with the South China Sea carrying one third of it (Borah, 2020). This sea has become home to some of the most intractable territorial disputes in Asia and a stage for intensifying strategic competition between Asia-Pacific powers as each pursues its respective national and regional interests. Increasingly, this competition appears to be leading to more frequent political and diplomatic disputes. The emerging geopolitics of the region are greatly connected to events 
in the Indian Ocean and the role of the American navy. The activeness of the India's growing involvement in the SCS and the role that Washington is playing in the region and argues that increasing American involvement are the causes of concern in Beijing (Christopher, 2019). The South China Sea disputes have been regarded as one of the major flashpoints in East Asia. Lying astride one of the world's most important trade routes, the South China Sea holds invaluable, yet largely untapped natural resources, with hydrocarbons (i.e., oil and gas) as the highprofile component. The insatiable demand for marine resources adds to the salience of this body of water (Ramadhani, 2019). With the increasing dispute, some countries act out of the coverage of the international maritime law. On 12 July 2016, the Permanent Court of Arbitration (PCA) in The Hague issued the award on The South China Sea Arbitration (The Republic of Philippines v. The People's Republic of China), which ruled in favor of the Philippines. The Philippines filed the case in 2013 without China's consent. China refused to take part in the proceedings and regarded the award 'null and void'(Ministry of Foreign Affairs, the People's Republic of China, 2016).

From these overlapping claims and the latest news, it is obvious that the South China Sea issue is very complicated to deal with. It seems that potential military conflicts are simmering in this region. As the biggest and most influential country among all the claimant states, China plays a vital role in the situation of this region. (Zhao, 2013) Will China trigger military conflicts over the South China Sea or will it cooperate with the Association of Southeast Asian Nations (ASEAN) countries in the joint development of this region? Realists tend to predict a military conflict will happen mainly because of the expanding economic ability of China and its ambition to become a great power. Whilst liberalists foresee a cooperation will arise because of the close economic linkage between China and ASEAN countries, serving as the biggest constraint on China's resort to force. This paper analyzes both the realists' and liberalists' perspectives and finally comes to the conclusion that cooperation, rather than a military conflict, is more likely.

\section{Realists' Perspective - Conflict is Unavoidable}

Realists consider state behavior as a 'reconstruction of interest-oriented, power-seeking activity' (Doyle 1997, 199). All nation countries engage in a non-sum game with a superiority of power, not an equality of power as the ultimate goal. Constitutionalism, like other forms of realism, describes the interstate politics as 'a state of war' because all of the nation countries are seeking power, or 'national interest' at the loss of the others (Doyle, 1997). In realists' opinion, desire for relative gains prevail that for absolute gains. When desire for relative gains is strong enough, then cooperation is more unlikely (Gill et al., 1988; Milner, 1992). In this case, China, as an enormous country, had suffered 'humiliation' of foreign countries for almost a century before it 'stood up'. With the expanding economic ability, China seems to cultivate its ability to become prosperous and strong again as what it was before the humiliated history. China swears it would never let any country to take its territory and it would protect its sovereignty from any intervention. China always claims that its sovereignty over the South China Sea is indisputable and it would protect its sovereignty by all means. While some of the ASEAN countries also claim their sovereignties on it. Because of the strategic importance of the South China Sea where the national interest of China lies, a military conflict between China and the ASEAN claimant countries seems to be simmering.

\subsection{Internal Reasons}

First and foremost, the huge population and its growth impose great pressure on natural resources and the growing living standard of the population increases the demand for energy resources. As a place abundant in natural and energy resources, the South China Sea attracts China's attention. As Deng Xiaoping once pointed out, even the population does increase no more, the problem of huge population will exist for some time. The most outstanding problem of China is that very few resources have been used by a large population even though China is abundant in natural resources (Garver, 1992). The huge population imposes great pressure on the currently developed resources thus the untapped abundant resources come into the spot light. There were several articles in the Jiefangjun bao (The People's Liberation Army Journal) elaborating the importance of the undeveloped maritime resources for the releasing of the pressure brought by the huge population and its growth (Garver, 1992). In the articles, great emphasis was attached to the South China Sea, a piece of untapped territory of China, where abundant natural and energy resources lie. The protection and usage of the oceans are significant to the security and development of the country (Garver, 1992). The great population and its increasing living standard puts China in great demand of energy resources. China was forced import oil in 1993 even though it has substantial reserves and will probably import 40 per sent of its estimated needs by 2010 (Dupont, 2001). China is likely to make a record of the world's fastest increase in energy consumption in the first decade of this century, up to the level of all the European developed nations combined from the current level of less than 40 per cent of the world average (Dupont, 2001). Given its annual growth rate of 10 per cent, the proven reserves in China would be exhausted within 15-20 years if without new found reserves (Dokken, 2001). Therefore, the South China Sea, in which only 
the Spratlys is estimated to contain from 1 billion to 105 billion barrels of oil (Gallagher, 1994), becomes the wonder drug to solve this energy problem.

Secondly, the expanding economic power enables China to modernize its military forces, especially naval force. The past two decades has witnessed amazing economic growth in China, with its Gross Domestic Product (GDP) quadrupled and an annual GDP growth rate of 8 per cent (CIA, 2003). The extraordinary economic growth provides a better weapon acquisition. In fact, the rates of economic growth can serve as a best indicator of the increase in the defense expenditures in the East Asia (Ball, 1993-1994). Generally speaking, the increase in defense expenditures is somewhat less than the growth of GDP (Ball, 1993-1994). Defense expenditure is a good indicator for countries to learn about each others' intention and capabilities of defense (Ding, 1996). But the vagueness and secrecy has 'clouded' (Huxley, 1998) China's defense expenditure hence it is difficult to learn its intention and capacity.

Despite all the vagueness of China's defense intention and capacity, some improvements in the defense ability, especially that of the naval force, can be detected. From the late 1980s, the strategy of the naval force has been changed from a jinhai fangyu (coastal defense) to a jinyang fangyu (offshore defense) which means it has extended its defense range, even more to cover the South China Sea (Chang, 1996). China has acquired a new class of destroyer which enables it to sustain operation farther from shore and for longer periods, an action according to its strategy changed to an offshore defense one. At the same time, China has enhanced its power-projection capabilities in the South China Sea by constructing an airbase and anchorages on Woody Island in the Paracel Islands (Ball, 1993-1994). Moreover, China's air forces has been strengthened in order to cooperate well with the naval force to realize the offshore defense strategy. Several types of modern aircrafts have been purchased from Russia and China has acquired an air-to-air refueling capacity for its naval air force which enhancing the range the air force can cover (Ball, 1993-1994). It is worth noting that economic growth is beneficial to the increase in the defense expenditure, but at the same time, military build-up could serve as a momentum for economic activities (Wang, 2001). Put it simply, economic growth and defense ability are mutually supportive to some extent.

Last but not least, China has never claimed that it will give up its indisputable sovereignty over the South China Sea and it has shown its reluctance to adopt multilateralism in the South China Sea issue. Based on its national interest, strategies adopted by China towards the South China Sea issue can be summarized as 'bilateral, informal and claimant states exclusive'. Although China has not ruled out the possibility of multilateral negotiation and cooperation on the South China Sea issue, its preference for bilateral over multilateral method of discussion is obvious (Lee, 1999; Valencia, 1993). Bilateral approach is better for China because it is the biggest party in this issue and bilateral method prevents the comparatively smaller ASEAN claimant countries from grouping together to bargain with China. China keeps the South China Sea issue off the agenda of ASEAN Regional Forum (ARF) and only engages in informal and non-binding negotiations. It insists that the 'code of conduct' should be informal and non-binding which makes them meaningless as the codes cannot deter any military clashes in this issue (Valencia, 2001). China's 'claimant states exclusive' strategy aims at keeping the U.S. out of the 'pie' (Lee, 1999; Lee, 1995; Lee, 2003). China is antagonized to the idea of bringing U.S. in this issue because it would dilute China's influence on this issue and make it more complicated (Lee, 1995). And China has successfully carried out its so-called 'creeping assertiveness' over the South China Sea without confronting U.S. military forces. From the above reasons, realists China decides its strategy on the South China Sea based on its national interests and its capacity. When time is ripe and China is strong enough, a military conflict between it and the ASEAN countries would be on the brink.

\subsection{External Reasons}

To begin with, the ASEAN claimant countries also face the accelerating economic development leading to greater demand for energy. The urbanization and economic development in the 'second tier of tiger economies' have resulted in higher demand for energy (Dupont, 2001). Although Vietnam and the Philippines probably become a modest net exporter and Malaysia is currently a significant energy supplier, the dramatically-increasing domestic demand and a decline in recoverable oil reserves worsen the situation and Malaysia may soon become an oil importer (Dupont, 2001). The maritime energy resources are naturally becoming attractive. In Southeast Asia more than 70 percent of the population resides in the coastal areas and they are highly reliant on the ocean resources and sea transportation (Næss, 2001). Also, the maritime fishery resources provide a source of food for the population and its growth. The per capita consumption of fish per year in this region, excluding Cambodia, is above the world average. Fish is the sole most vital source of animal protein for the people in most of the ASEAN countries (Wang, 2001). Therefore, the ASEAN claimant countries have an important stake in the South China Sea which is abundant in both energy and fishery resources. 
With the retreat of U.S. military forces and influence in the Pacific-Asian region and the ever-accelerating growth in China's economy, the ASEAN countries feel under threat of China hence they all engage in military build-up (Ball, 1993-1994; Acharya, 2001). Data reveals that a general rise in defense expenditure has been found in the post-Cold War era (Acharya, 2001), partly because of the economic growth in these countries and partly the removal of the U.S. military forces. The focus of the region's military build-up is basically the development of the air and naval forces through the purchase of advanced fighter planes, maritime patrol aircraft, large surface and so on (Acharya, 2001). The military build-up in this region generally targets at extra-regional powers, particularly China (Acharya, 2001). These ASEAN claimant states, especially Malaysia and Singapore, have 'matched or even surpassed' China in several technical areas with the acquisition of American advanced weapons (Chang, 1996). It is exaggerating to describe the military-build up in this region as 'an arm race', but admittedly, the competition in military forces is becoming fiercer than ever before which imposes a potential of military conflicts among the claimant countries.

In fact, there have been some clashes between China and Vietnam, and China and the Philippines. The earliest clash between Vietnam and China happened in 1974 when South Vietnam sent troops to five islands in the Spratlys, and both sides ended up in a small naval battle in the Paracels (Ji, 1998). In 1988, the second clash happened. The Chinese navy made its first major survey of the Spratlys, avoiding the islands and reefs already occupied by Vietnam in order not to trigger military clashes, but a naval clash was still not unavoidable and 70 Vietnamese sailors lost their lives (Ji, 1998; Tønnesson, 2003). The third conflict was in 1992 when China and an American company Crestone reached an agreement of oil exploitation in the area where overlapping claims of China and Vietnam exist (Buszynski, 1997-1998). Therefore, Vietnam countered the Chinese Crestone concession by awarding a rival concession to Conoco, another American company (Tønnesson, 2003). And lastly, Vietnam protested against China's oil test drilling in 1997 and then China suspended its plan (Ji, 1998). There were two main clashes between China and the Philippines: one was in 1995, China's occupation of Mischief Reef and the other was in 1997, the Scarborough Reef incident. Fortunately, there were no real military clashes between the two countries, but only the verbal warning and protest. These countries rushed to occupy these small outcroppings in order to establish unique territorial claims to both and Exclusive Economic Zone (EEZ) and a continental shelf in accordance with the United Nations Convention on the Law of the Sea (UNCLOS) promulgated in 1982 (Burgess, 2003). 


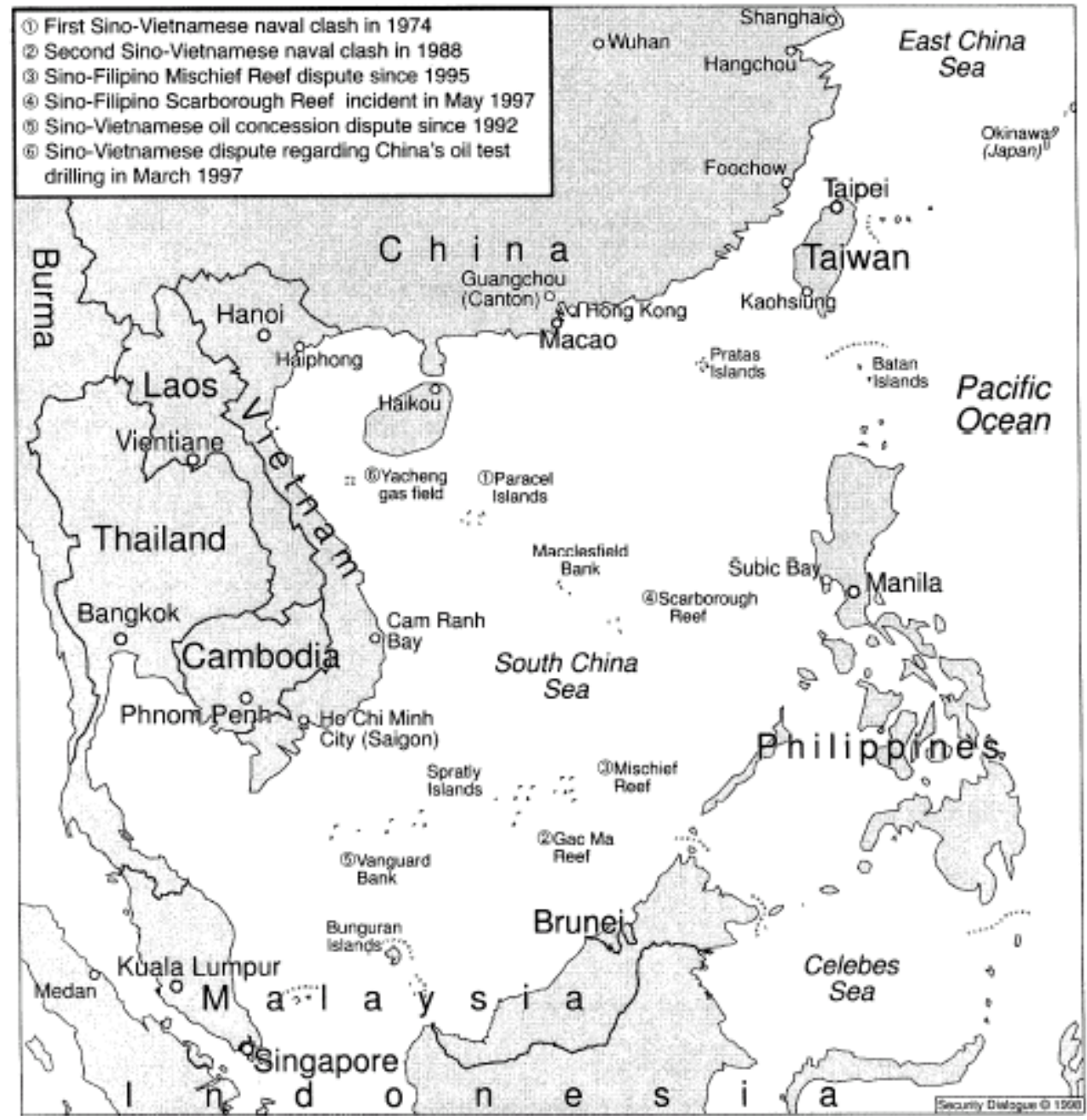

Figure 2. The Clashes between China and Vietnam, and China and the Philippines (Ji, 1998)

From the external reasons, realists hold that the ASEAN claimant states, having their own national interests, feel under threat of China. Thus these countries and China are in a non-sum competition, seeking for the superiority of power over others. Military clashes are simmering. Once there is some 'over-acting' of China, military conflicts between China and the ASEAN claimant countries, would be probably triggered.

\section{Liberalists' Perspective - Cooperation is Desirable and Feasible}

In general, liberalists believe that the expanding trade and economic interdependence among countries can help to reduce military conflicts and enhance chances for cooperation (Gilpin, 1987). The size of the Chinese market plus the lure of quick profits in China's booming economy attract ASEAN countries (Buszynski,1995). Trade between China and the ASEAN countries has increased dramatically from 4, 528,694 US dollars in 1993 to 31,552,090 US dollars in 2001 (ASEAN Trade Data, 2004). The economic interdependence imposes a great constraint on the military conflicts between China and the ASEAN claimant countries. As Robert Powell puts it, when using force is costly, cooperation will emerge (Milner, 1992). In this case, it is costly for China or any ASEAN countries to use force to settle the South China Sea dispute.

\subsection{Internal Reasons}

Above everything else, China is still a relative poor country despite its eye-catching economic growth. In the year 2000 , there were still approximate 360 million people living on less than 1 US dollar per day in China (Williams, 2004). The most outstanding problem hindering China's development is the widening gap of income between coastal areas and hinterland (Gallagher, 1994). The imperative task is to develop its economy, particularly the economy of the hinterland, which requires a stable and peaceful environment. China has not expelled any ASEAN occupants from the Spratlys because it has the importance of regional stability in mind (Tønnesson, 2000). The 
current Chinese strategy focus is modernization and economic development at home (Goldstein, 2001; Yahuda, 2003). Its foreign policy serves this purpose: maintaining stability with less need to address immediate military challenges and making full use of the less hostile international environment conducive to China's integration into international economy (Goldstein, 2001; Yahuda, 2003). China has adopted 'cooperative security' to release the fear of a 'greater' China of the relatively small neighboring countries, particularly the ASEAN claimant countries. As Huxley (1998) puts it, 'given its increasingly complex and vital economic linkages with its region, it is in China's self-interest to behave with restraint.'

The second constraint on China's military actions in the South China Sea issue is that its military forces lag behind that of developed countries. Its military capacity is not strong enough to reach and control the entire South China Sea. In spite of the increase in the defense expenditure due to the dramatic economic growth and some improvements in the military forces, China still falls behind the West as much as twenty years (Gallagher, 1994). The biggest obstacle of China's military build-up is lack of money. As a relative poor country, its military buildup is through purchase of advanced weapons. The People's Liberation Army Air Force (PLAAF) lacks the ability in protecting the People's Liberation Army Navy (PLAN) in the operation in the South China Sea (Gallagher, 1994). The two major problems facing PLAAF are range and training: most fighters and aircrafts still cannot reach as far as the disputed islands even from the forward air bases; and the training time of Chinese pilots is far more less than that of their counterparts. The most worrisome problem is that 'Chinese pilots are so unskilled that Russian pilots have to deliver the planes to China's air base' (Chang, 1996). China only possesses seventy-two Su$27 \mathrm{~s}$ which is such a small amount for a big country like China. And the South China Sea issue is not on the top of priority, thus it is impossible to stake all these new and advanced planes in this region (Chang, 1996). The situation of the PLAN is no better than that of the PLAFF. There are virtually no ships in the PLAFF equipped with modern antiaircraft missile systems and the submarine fleet is equipped with the 1950s Soviet designs even though this fleet is the world's second largest one (Gallagher, 1994). Even if China can overcome all these obstacles and occupy all the islands by expelling the occupants from the ASEAN claimant countries, it is still very challenging for China to hold these small islands and defend any would-be counter-attacks because a great cost is involved (Tønnesson, 2000). While China possesses limited number of foreign-manufactured modern weaponry, its ASEAN counterparts already hold the most up-dated locally manufactured equipment (Gallagher, 1994).

The cost of using force to settle the South China Sea dispute is enormous for China. Therefore, it seeks to solve this problem by cooperation with the ASEAN claimant countries. China is very cautious about any action which will antagonize the ASEAN counterparts and becomes more and more active in cooperation and confidencebuilding measures. The new strategy adopted by China is 'shelving the sovereignty issue and pursuing the joint development of the South China Sea'. In the case of Mischief Reef, most of China's naval forces had been withdrawn and the Philippines fishermen were invited to use the facilities on the reef. Concerning the drilling test in 1997, China's exploration rig withdrew after Vietnam's protest (Ji, 1998). These reveal China's caution dealing with the ASEAN counterparts on the South China Sea issue and its sincerity to cooperate with the ASEAN countries. China joined ARF upon its establishment in 1994 and since then, it has become more and more active in this multilateral forum to deal with ASEAN countries to enhance transparency and build confidence in order to ease the 'China Threat' felt by some ASEAN countries (Yahuda, 2003). China's attitude towards the South China Sea issue in this forum was changed forum had been changed from resistance to putting this issue on the agenda to acceptance of discussing this issue in an informal multilateral way (Lee, 1999). China also participated in the 'Managing Potential Conflicts in the South China Sea' workshop led by Indonesia. Although the controversial territorial issue was shelved in this workshop, an opportunity was offered to participant countries to voice opinions at a transparent level to serve as a confidence-building measure (Acharya, 2001). In 1999, China even agreed to transfer negotiations on a code of conduct from the informal level to formal level, which showed its sincerity in cooperating with the ASEAN counterparts. 'China is beginning to seriously consider the possibility of benefiting more from a regional order compatible with the ASEAN interest' (Odgaard, 2003).

\subsection{External Reasons}

Without the 'shadow of the past' (Gill et al., 1988), the prospect of cooperation between the ASEAN and China is bright. Security relation is often influenced by the history: if the people of A country had ever been humiliated and ruled by force by B country, people of A country would feel antagonized towards B country and it would be challenging for A country to cooperate with B country because "the shadow of the past outweighs the shadow of the future' (Gill et al., 1988). As Anna Dominique Coseteng once said, 'Although China have been around the Philippines for 3,000 years, they have not shown any signs of wanting to control government policies or interfere in our affairs' (Roy, 1994,). Before Western colonialism intruded Asia, the relation between China and the countries (mandalas) in Southeast Asia was a center-periphery relation surrounded by a circle comprising tributary polities, 
not by force or any compulsory power (Amitav, 2000). Therefore, the ASEAN countries nowadays eye China with 'concern' but not 'alarm' (Whiting, 1997). The former Senior Minister of Singapore Lee Kuan Yew and Malaysian Prime Minister Mahathir Mohamad had once shown their disagreement with the 'China threat' argument (Roy, 1994).

There is an internal conflict in the ASEAN countries concerning the attitude towards China on the South China Sea issue. An 'anti-China' coalition has not established hence chances are still there that China and the ASEAN claimant countries seek cooperation development. The ASEAN was founded on the base of "countering the common external threat' when Vietnamese invaded and occupied Cambodia. Then its main focus is reduction of the danger of former Soviet, Chinese and American intervention in affairs of this region (Acharya, 1997). However, the ASEAN claimant countries cannot agree on the common base of 'countering the external threat'. First, they cannot reach an agreement on the level of the involvement of U.S. and China in the affairs of this region; second, opinions vary from country to country whether the cooperation should be binding and tangible; and last, the ASEAN claimant countries cannot agree on the scope of a code of conduct (Odgaard, 2003). These three differences result in different foreign policy positions. Therefore, it is not surprising that there is a disunity in dealing with China on the South China Sea issue among ASEAN claimant countries. The three most important ASEAN claimant counterparts have different position towards China on this issue. The South China Sea issue is a deep-rooted potential threat to the Sino-Vietnamese rapprochement resulted from their common communist ideology and the non-intervention principle from the same fear of the U.S. (Tønnesson, 2003). Vietnam is China's best chance to settle the South China Sea dispute by bilateral talks if that is the only way China sincerely desires (Tønnesson, 2003). The Philippines might be the most 'unfriendly' country towards China because of the U.S.Philippines alliance (Austin, 2003). When Malaysia appeared to move closer to China's position of seeking bilateral solutions, the Philippines felt betrayed by Malaysia (Acharya, 2001). The ASEAN claimant countries have not formed a coalition against China as the 'external threat' on the South China Sea issue which provides chance for China and these counterparts to pursue the prospect of cooperation.

The most practical and feasible method to deal with the South China Sea issue is that China and the ASEAN counterparts shelve the territorial disputes but cooperate in the joint development. And environmental cooperation is a good start. As Mathews argues, the environmental degradation will hinder economic development which will then result in political instability (Breslin, 1997). The importance of environmental security cannot be ignored. As mentioned before in this paper, China and the ASEAN counterparts face the common environmental challenges brought by the increase of population growth and the great need of energy and food resources. The states around the South China Sea are interdependent in regards of the human environment (Dokken, 2001), which can serve as a base for joint development and cooperation. Moreover, the less-controversial environmental cooperation is raised as a confidence-building measure to enhance transparency and communication among the claimant countries (Dokken, 2001). The coming into being of the concept of environmental security symbolizes that a comprehensive security concept consists of not just political and military security (Dokken, 2001) and the realists' constraint interpretation of security has become out-dated (Dokken, 2001). Environmental security, as put in the book 'Security: A New Framework for Analysis', is one of the five elements composing the concept security (Dokken, 2001). The environmental security resulting in environmental cooperation can serve as the driving force for the joint development of the South China Sea between China and the ASEAN claimant countries in current awkward situation of lack of any feasible driving force (Dokken, 2001). The current two programs engaging in this environmental cooperation are multilateral informal meetings 'Managing Potential Conflicts in the South China Sea' and an environmental program attached to the United Nations Environmental Programme (UNEP) (Næss, 2001). These two programs provide platforms for the environmental cooperation between China and the ASEAN claimant countries in order to enhance confidence-building measures and avoid potential conflicts.

\section{Cold War Mentality of "China Threat"}

With the deepening of reform and opening-up, the economy of China has developed rapidly. It is currently the world's second largest economy, largest trading economy, second largest destination of foreign direct investment (FDI), largest manufacturer, and largest holder of foreign exchange reserves" (Wayne, 2014). In Obama's speech at the University of Queensland clearly mentioned about China "by virtue of its size and its remarkable growth, China will inevitably play a critical role in the future of this region" (Obama, 2014). Coincidentally, South and East China Sea disputes have endowed United States a better opportunity to mobilize the China's neighboring countries- with others, Japan, Australia and Philippines. On the sideline talks of G20 Summit US, Japan and Australia revived there already agreed security commitments in the region which China feels is to counter her rise (Alam, 2020). However, some propaganda machines are overstating China's economic and military power and the saying of "China's rising" is ballyhooed. In order to improve the bilateral relations, China wants to become a more 
responsible actor in the region, wishing to share common prosperity with itts neighbors through expanding trade, outward investment and foreign assistants to some other less developed ASEAN member states (Shen, 2011). Besides, China also has increased investment in some African countries to build up an image of big country and show China's sense of responsibility for the international community. It's reported that when our country expand trade and increase investment in less developed countries, the comment "the outflow of merchants investing in their ancestral home and had caused the shortage of the native investment becoming much more severe. Ironically, the "China Threat" has become more entrenched so far. But China has promised again and again to follow unswervingly the path of peaceful development because peace and development are the themes of The Time. Common interests and win-win situation are in pursuit of.

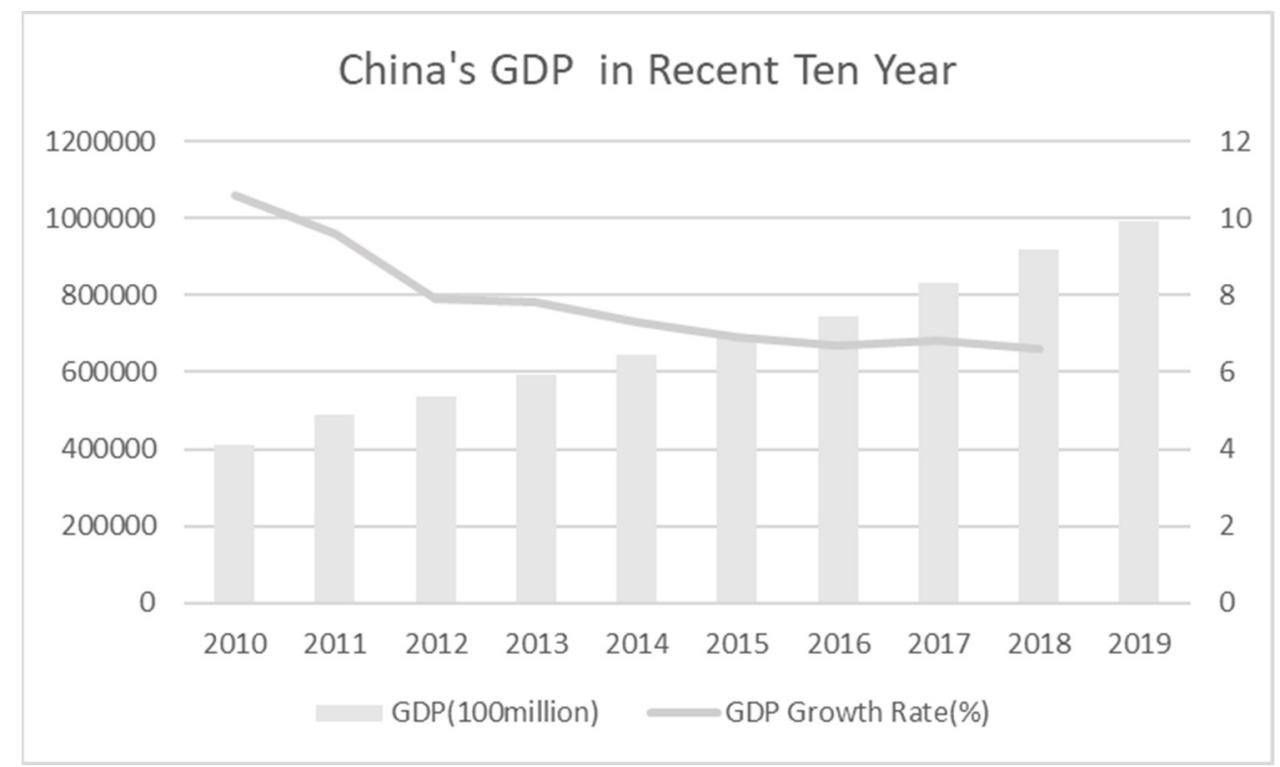

Figure 3. The GDP of China recently (National Bureau of Statistics, 2020)

\section{Conclusion}

There is no denying that the South China Sea dispute plays a vital role in the relation between China and the ASEAN countries. The overlapping claimants over the South China Sea, which is abundant in fishery and energy resources and is an important sea lane, make it one of the most sensitive issues in the Southeast Asia. After the analysis of realists' and liberalists' perspective, I come to the conclusion that although there are still territorial disputes concerning the South China Sea between China and the ASEAN counterparts, cooperation, rather than a state of war, is more likely.

With the pressure imposed by growth in population and economic development, China is in great demand of energy resources while the South China Sea is a bonanza of energy resources. Admittedly, China has a great stake in the South China Sea and it always claims that its sovereignty is disputable. The past two decades have witnessed striking economic growth in China and its military forces have been modernized and the capacity has been improved dramatically. Therefore, the ASEAN counterparts view a growing China with suspicion and the realists have estimated that China has the will and the ability to use force to claim its sovereignty over the South China Sea in reality.

In my opinion, the realists exaggerate 'China threat' and they are blind towards the devastating consequence of China's using force in the South China Sea issue. China has neither the 'will' nor the 'ability' to use force to control the entire South China Sea in the foreseeable future. Subjectively, China's imperative task is to carry out the economic modernization at home and maintain a less hostile international environment conducive to the economic modernization. Using force is counter-productive to its foreign policy which focuses on releasing the fear of the relative small neighboring countries and maintaining a stable and peaceful environment. Objectively, as a relative poor country, with approximate 360 million people living on less than one US dollar per day, China does neither have the economic capacity nor the military capacity which still lags behind the West for twenty years, to launch a war against the ASEAN counterparts to regain its sovereignty over the South China Sea. The devastating consequence of using force of China in the South China Sea may be: first, the ASEAN counterparts would form a coalition against China; second, it would trigger a revision by some states of the two-China policy by recognizing 
Taiwan; third, other extra-regional new factors may be introduced in the South China Sea such as Japan would rearm and U.S. would get involved; and finally, the conspiracy of 'demonizing China' would come to a success and the overseas Chinese communities would suffer a hostile policy. The cost of using force to settle this dispute is too enormous that cooperation is a much wiser option. When using force is costly, cooperation is more likely. In fact, China is becoming more and more active in the joint development of the South China Sea: engaging in the ARF forum, participating in the environmental cooperation programs and even engaging in informal multilateral dialogues. China has shown its sincerity to cooperate with the ASEAN claimant countries which is in accordance with its 'cooperative security' foreign policy. In a nutshell, with many constraints on it, China will not use force to settle the South China Sea dispute in the foreseeable future.

\section{References}

Acharya, A. (1997). Ideas, Identity, and Institution-building: From the "ASEAN Way" to the "Asia-Pacific Way"? The Pacific Review, 10(3), 319-346. https://doi.org/10.1080/09512749708719226

Acharya, A. (2000). The Quest for Identity: International Relations of Southeast Asia. Singapore: Oxford University Press.

Acharya, A. (2001). Constructing a Security Community in Southeast Asia: ASEAN and the Problem of Regional Order. London and New York: Routledge.

Alam, Z. (2020). South China Sea Dispute: An Assessment of India's Response. Journal of Innovation and Social Science Research, 7(8), 26-29.

ASEAN Trade Data. (2004). Retrieved from http://202.154.12.3/trade/publicview.asp.Accessed on 30/04/2004

Austin, G. (2003). Unwanted Entanglement: The Philippines' Spratly Policy as a Case Study in Conflict Enhancement? Security Dialogues, 34(1), 41-54. https://doi.org/10.1177/0967010603034001675

Ball, D. (1993-1994). Arms and Affluence: Military Acquisitions in the Asia-Pacific Region. International Security, 18(3), 78-112. https://doi.org/10.2307/2539206

Borah, U. (2020). The South China Sea dispute: Will it impact Japan's security policy? Maritime Affairs: Journal of the National Maritime Foundation of India, 16(1). https://doi.org/10.1080/09733159.2020.1785033

Burgess, J. P. (2003). The Politics of the South China Sea: Territorial and International Law. Security Dialogues, 34(1), 7-10. https://doi.org/10.1177/09670106030341002

Buszynski, L. (1995). China and the ASEAN Region. In S. Harris, \& G. Klintworth (Eds.), China as a Great Power: Myths, Realities and Challenges in the Asia-Pacific Region (pp. 161-183). New York: St. Martin's Press.

Buszynski, L. (1997-1998). ASEAN's New Challenges. Pacific Affair, 709(4), 555-577. https://doi.org/10.2307/2761323

Buszynski, L. (2012). The South China Sea: Oil, Maritime claims, and U.S. - China Strategic Rivalry. Washington Quarterly, 35(2), 139-156. https://doi.org/10.1080/0163660X.2012.666495

Chang, F. K. (1996). Beyond the Unipolar Moment: Beijing's Reach in the South China Sea. Orbis, 40, 353-374. https://doi.org/10.1016/S0030-4387(96)90002-2

Christopher, K. C. (2019). Nalanda Roy, The South China Sea Dispute: Past, Present, and Future. Journal of Asian Security and International Affairs, 6(1), 96-105. https://doi.org/10.1177/2347797018823973

Ding, A. S. (1996). China's Defense Finance: Content, Process and Administration. The China Quarterly, (146), 428-442. https://doi.org/10.1017/S0305741000045094

Dokken, K. (2001). Environment, Security and Regionalism in the Asia-Pacific: Is Environmental Security a Useful Concept? The Pacific Review, 14(4), 509-530. https://doi.org/10.1080/09512740110087311

Doyle, M. W. (1997). Ways of War and Peace. New York and London: W. W. Norton \& Company.

Dupont, A. (2001). East Asia Imperilled: Transnational Challenges to Security. Cambridge: Cambridge University Press.

Gallagher, M. G. (1994). China's Illusory Threat to the South China Sea. International Security, 19(1), 169-194. https://doi.org/10.2307/2539152

Garver, J. W. (1992). China's Push through the South China Sea: The Interaction of Bureaucratic and National Interests. The China Quarterly, 132(2), 999-1028. https://doi.org/10.1017/S0305741000045513 
Gill, S., \& David, L. (1988). The Global Political Economy: Perspectives, Problems and Policies. London: Harvester Wheatsheaf.

Gilpin, R. (1987). The Political Economy of International Relations. Princeton: Princeton University Press. https://doi.org/10.1515/9781400882779

Goldstein, A. (2001). The Diplomatic Face of China's Grand Strategy: A Rising Power's Emerging Choice. The China Quarterly, 168, 835-864. https://doi.org/10.1017/S000944390100050X

Huxley, T. (1998). A Threat in the South China Sea? A Rejoinder. Security Dialogue, 29(1), 113-118. https://doi.org/10.1177/0967010698029001011

Ji, G. (1998). China Versus South China Sea Security. Security Dialogue, 29(1), 101-112. https://doi.org/10.1177/0967010698029001010

Lee, L. (1995). ASEAN and the South China Sea Conflicts. The Pacific Review, 8(3), 531-543. https://doi.org/10.1080/09512749508719155

Lee, L. (1999). The South China Sea: China and Multilateral Dialogues. Security Dialogue, 30(2), 165-178. https://doi.org/10.1177/0967010699030002004

Lee, L. (2003). China, the U.S.A. and the South China Sea Conflicts. Security Dialogue, 34(1), 25-39. https://doi.org/10.1177/0967010603034001673

Milner, H. (1992). International Theories of Cooperation among Nations: Strengths and Weakness. World Politics, 44(2), 466-496. https://doi.org/10.2307/2010546

Ministry of Foreign Affairs, the People's Republic of China. (2016, July 12). Statement of the Ministry of Foreign Affairs of the People's Republic of China on the Award of 12 July 2016 of the Arbitral Tribunal in the South China Sea Arbitration established at the request of the Republic of the Philippines.

Muscolino, M. S. (2013). Past and Present Resource Disputes in the South China Sea: The Case of Reed Bank. Cross-Currents: East Asian History and Culture Review, 2(2), 447-477. https://doi.org/10.1353/ach.2013.0026

Nass, T. (2001). Environmental Cooperation around the South China Sea: The Experience of the South China Sea Workshops and the United Nations Environment Programme's Strategic Action Programme. The Pacific Review, 14(4), 553-573. https://doi.org/10.1080/09512740110087339

National Bureau of Statistics. Retrieved from https://data.stats.gov.cn/

Obama, B. (2014, November 15). Remarks by President Obama at the University of Queensland. Washington, DC: White House, Office of the Press Secretary.

Odgaard, L. (2003). The South China Sea: ASEAN's Security Concerns about China. Security Dialogue, 34(1), 11-24. https://doi.org/10.1177/09670106030341003

Ramadhani, E. (2019). Is assertiveness paying the bill? china's domestic audience costs in the south china sea disputes. Journal of Asian Security \& International Affairs, 6(1), 30-54. https://doi.org/10.1177/2347797018823342

Reeves, L. (2019). The South China Sea Disputes: Territorial and Maritime Differences Between the Philippines and China. Journal of Global Faultlines, 6(1), 39-61. https://doi.org/10.13169/jglobfaul.6.1.0039

Roy, D. (1994). Hegemon on the Horizon? China's Threat to East Asian Security. International Security, 19(1), 149-168. https://doi.org/10.2307/2539151

Shen, H. (2011). South China Sea Issue in China -ASEN Relations: An Alternative Approach to Ease the Tension. International Journal of China Studies, 2(3), 585-600.

Tønnesson, S. (2000). China and the South China Sea: A Peace Proposal. Security Dialogue, 31(3), 307-326. https://doi.org/10.1177/0967010600031003005

Tønnesson, S. (2003). Sino-Vietnamese Rapprochement and the South China Sea Irritant. Security Dialogue, 34(1), 55-70. https://doi.org/10.1177/09670106030341006

Valencia, M. J. (1993). Spratly Solution Still at Sea. The Pacific Review, 6(2), 155-170. https://doi.org/10.1080/09512749308719033

Valencia, M. J. (2001). Building Confidence and Security in the South China Sea: The Way forward. In A. T. H. Tan, \& J. D. Kenneth Boutin (Eds.), Non-Traditional Security Issues in Southeast Asia (pp. 528-569). 
Singapore: Select Publishing for Institute of Defense and Strategic Studies.

Wang, K.-H. (2001). Bridge over Troubled Waters: Fisheries Cooperation as a Resolution to the South China Sea Conflicts. The Pacific Review, 14(4), 531-551. https://doi.org/10.1080/09512740110087320

Wayne M. M. (2014). China's Economic Rise: History, Trends, Challenges, and Implications for the United States. Washington, DC: Congressional Research Service.

Whiting, A. S. (1997). ASEAN Eyes China: The Security Dimension. Asian Survey, 37(4), 299-322. https://doi.org/10.2307/2645650

Williams, F. (2004, February 25). Rethink Urged on Global Economy. Financial Times, p.9.

Yahuda, M. (2003). Chinese Dilemmas in Thinking about Regional Security Architecture. The Pacific Review, 16(2), 189-206. https://doi.org/10.1080/0951274032000069642

Zhao, H. (2013). The South China Sea Dispute and China-ASEAN Relations. Asian Affairs, 44(1), 27-43. https://doi.org/10.1080/03068374.2012.760785

\section{Copyrights}

Copyright for this article is retained by the author(s), with first publication rights granted to the journal.

This is an open-access article distributed under the terms and conditions of the Creative Commons Attribution license (http://creativecommons.org/licenses/by/4.0/). 